\title{
EFFECTS OF A CARBENDAZIM-MANCOZEB FUNGICIDAL MIXTURE ON SOIL MICROBIAL POPULATIONS AND SOME ENZYME ACTIVITIES IN SOIL
}

\author{
FAWOLE O. B.* ALUKO M. and OLOWONIHI T. E. \\ Department of Agronomy, University of Ilorin, Nigeria. \\ yemisifawole@yahoo.com
}

\begin{abstract}
The effects of a Carbendazim-Mancozeb fungicidal mixture on microbial populations and some enzyme activities of three selected soils of Kwara State, Nigeria were studied. The soil dilution method was used to isolate bacteria, fungi, actinomycetes and some functional microbial groups from treated soils. Cultivation and enumeration of the soil microorganisms were made on different selective media. Assays for cellulases and pectinases in the treated soils were carried out. The populations of actinomycetes, bacteria and fungi were reduced significantly by the application of the fungicide. The fungicide applied at a concentration of $2.34 \mathrm{mg} / \mathrm{kg}$ soil had a greater $(p<0.05)$ inhibitory effect than the recommended concentration of $1.67 \mathrm{mg} / \mathrm{kg}$ soil. The populations of nitrogen fixers nitrifying bacteria and cellulolytic organisms were also significantly $(p<0.05$.) reduced at the two concentrations. The fungicidal mixture equally lowered the cellulose and pectinase enzyme activities in soil significantly, with a return to normalcy by 60 days after treatment. A re-establishment of the soil microbial populations was observed by 21 days after treatment. It was concluded that the use of the Carbendazim-Mancozeb mixture should be with caution since it reduced the populations of ecologically important non-target organisms and that the recommended concentration should be adhered to.
\end{abstract}

Keywords: Carbendazim-Mancozeb, Microbial Populations, Pectinases, Cellulases

\section{INTRODUCTION}

Chemical technology has expanded tremendously during the past fifty years with an estimated 100,000 chemicals produced and used commercially (Mitchell et al, 2002). Helsel (1987) estimated that some $17 \%$ of applied pesticides are fungicides. Fungi are the most numerous plant disease causing organisms.

Carbendazim, a systemic fungicide has extensive application world-wide (WHO/FAO, 1994, Pesticide news, 2002) while Mancozeb, a dithiocarbamate nonsystemic fungicide is also used widely as a contact fungicide to control fungal diseases of plants. Some pathogenic fungi are known to have developed resistance to many systemic fungicides (Copeland, 2005). However, protectant fungicides are known to moderate the tendency of systemic compounds to cause resistance to develop. Carbendazim is often therefore combined with other fungicides that have different 
modes of action to combat resistance of pathogenic fungi to Carbendazim (JMPR, 1995). Mancozeb is used regularly in combination with some systemic fungicides. A Carbendazim-Mancozeb mixture "TEAM" is marketed and used by farmers in Kwara State, Nigeria for the control of fungal diseases of cowpea, maize, and fruit crops on their farms.

The effect of pesticides on non-target soil micro flora, microbial processes and soil borne plant diseases has been a major source of concern for soil microbiologists over the years. Bending et al. (2007) reported that some pesticides significantly reduced dehydrogenase activity in soil to varying extents and reduce mineralization of subsequent applications of other pesticides. Microbial activities are negatively affected by chemicals intensively used in agriculture (Jitka et al., 2009). It is therefore necessary to have information on the effect of commonly used pesticides on soil microbial flora.

The objectives of this study therefore were to investigate the effects of a Carbendazim Mancozeb fungicidal mixture, "TEAM" on the population of various groups of bacteria, fungi and actinomycetes in soil as well as the effects of cellulose and pectinase activities in treated soil.

\section{MATERIALS AND METHODS \\ Determination of physicochemical properties of soil samples}

Three soils each from two local government areas of Kwara State were used in this study. The $\mathrm{pH}$ of soil samples was determined in water suspension with a Kent $\mathrm{pH}$ meter 7020 and the total nitrogen by macro kjeldal distillation method as described by Bremner and Mulvaney (1982). The organic matter content was determined by Walkley and Black method (1934) while the soil texture was determined by the hydrometer method of Bouyoucos (1951). The physicochemical properties of the soils are shown in Table 1.

\section{Soil treatment}

'TEAM' a fungicidal mixture of Carbendazim (1\% WP) and Mancozeb (63\% WP) (manufactured by Meghman industries limited, Gujarat, India) was used for the study. Using a randomized complete block experimental design, the fungicidal mixture was applied at the following rates: $0 \mathrm{mg} / \mathrm{kg}$ soil (control); $1.67 \mathrm{mg} / \mathrm{kg}$ soil (recommended rate), and $2.34 \mathrm{mg} / \mathrm{kg}$ soil (high rate). Eight kilograms of $2 \mathrm{~mm}$ sieved soil samples spread thinly on plastic sheeting was sprayed with the fungicidal mixture using a hand sprayer. The treated soil was then mixed and packed into plastic pots and incubated at room temperature under aerobic condition without vegetation. Sterile water (200ml/pot) was added 48hourly to keep the soil moist. All treatments were in triplicates. At $7,14,21,28$ and 60 days, soil samples were taken aseptically for various determinations. 


\section{Microbial counts}

The soil samples were suspended in sterile water $(10 \% \mathrm{w} / \mathrm{v})$. Ten fold serial dilution of the soil suspension were then made in sterile water. Fungi and bacteria were isolated and enumerated on Potato Dextrose Agar (PDA) supplemented with 1\% streptomycin and Nutrient Agar (NA) media respectively using the standard plate count method (Benson, 1998). Actinomycetes were isolated by phenol treatment method (Lawrence, 1956). PDA plates were incubated at $28 \pm 2^{\circ} \mathrm{C}$ while NA and phenol treated plates were incubated at $35 \pm 2^{\circ} \mathrm{C}$. Selective media used in isolation of some functional groups of micro-organisms are as follows: (1) media of Doneche et al. (1983) which contained carbon source for aerobic nitrogen fixers and glucose for anaerobic nitrogen fixers (2) media of Benson (1998) which contained ammonium sulphate as N source for nitrite producers and sodium nitrite for nitrate producers (3) Media of Staples (1973) which contained cellulose powder as $\mathrm{C}$ source for cellulolytic microbes. All determinations were made in triplicates. Plates were incubated at $30 \pm{ }^{0} \mathrm{C}$ under aerobic and anaerobic conditions. Microbial colonies were counted and expressed as number per gram of soil.

\section{Stastistical Analysis:}

Data obtained were subjected to Analysis of Variance (ANOVA) using the Genstat 3.5 package. Means were separated using LSD at $\mathrm{p}<0.05$.

\section{Enzyme assays:}

Cellulase assay: This was based on the breakdown of cellulose to reducing sugars using the dinitrosalicyclic acid (DNSA) reagent. The reaction mixture was made up of $0.5 \mathrm{ml}$ enzyme filtrate and $1 \mathrm{ml}$ of carboxymethyl cellulose in citrate hydroxide buffer solution ( $\mathrm{pH}$ 5.57). Optical density was measured at 575nm using a Camspec M 105 spectrophotometer. A unit of enzyme activity was defined as unit of enzyme in $1 \mathrm{ml}$ of reaction mixture that has reducing sugars equivalent to $10 \mu \mathrm{g}$ of glucose (Miller, 1959).

Pectinase assay: This was based on viscometric method of Robot and Barrath (1972). One unit of the viscosity reducing activity is defined as the time necessary for $50 \%$ reduction in viscosity under assay condition. Determinations were in triplicates for each soil sample at 7,28 and 60 days after treatment.

\section{RESULTS AND DISCUSSION}

The effects of varying concentrations of TEAM fungicide on populations of bacteria, fungi and actinomycetes in soil are shown in Table 2 . The properties of the soils used for the study (texture, organic matter content and $\mathrm{pH}$ ) as shown in Table 1 supported the proliferation for a variety of microorganisms. The untreated soils had significantly higher microbial populations than the treated soils. Inhibitory effects of 
the fungicidal mixture on fungi as well as non-target bacteria and actinomycetes even at recommended rates of the fungicide were observed. Pozo et al. (1994) reported that total platable fungal populations, denitrifying bacteria and aerobic diazotrophs were significantly decreased by agricultural doses of Mancozeb while total platable bacteria were not affected by the addition of Mancozeb. They concluded that some microbial groups can tolerate agricultural doses of this fungicide. The high concentrations of the fungicide used in the present study has a significantly higher inhibitory effect on bacteria and actinomycetes than the recommended concentrations while there were no significant differences in fungal counts at both concentrations up to 14 days after treatment. This suggests that application of TEAM at rates higher than the recommended rate while not contributing any extra impact on inhibiting the target groups affects the environment negatively by its action on non-target groups of soil living organisms. An evidence of weak phytotoxicity with the use of Carbendazim, especially at higher doses, in a study on tobacco was reported by Garcia (2002).

A re-establishment of microbial populations was observed in this study by 21 days after treatment. According to Burrows and Edwards (2004) the effects of Carbendazim on soil microflora are never long lasting. The changes in microbial populations attributed to Mancozeb application in soil have also been found to be temporary and reversed within few months. Report on the field half life of Mancozeb varies from one to seven days (US EPA, 2000). On the other hand, Carbendazim has a half life of 6-12 months on bare soil and 3-6months on turf soils (JMPR, 1995).

A significant reduction $(\mathrm{p}<0.05)$ in the numbers of nitrogen transforming microorganisms was observed in soils treated with the fungicidal mixture (Table 3 ). Reductions in population of soil organisms and soil nitrification have been reported at Mancozeb concentrations ranging from normal to 10 times normal field rate (Jitka et al., 2009). The fungicidal mixture reduced the population of cellulolytic microorganisms significantly (Table 4). Whereas there were no significant differences in populations of cellulolytic fungi with the use of high fungicide concentration and at the recommended concentration, the cellulolytic bacteria populations were significantly lowered by the high fungicide rate than the recommended rate. The effects of the fungicide on cellulolytic microorganisms were further confirmed by reduced cellulase activity observed with fungicide application (Table 5).

Cellulase activity was significantly lowered with high concentration of fungicide. Mancozeb has been reported to affect enzyme activities in soil (Vyas, 1988). The differences in cellulose activities of treated soils and untreated soils were no longer significant at 60 days after treatment. This is probably as a result of the near full reestablishment of the cellulolytic microorganisms in treated soils by 60 days after treatment.

Pectinase activity was also lowered significantly in treated soils as shown in Table 5. A significant reduction in the activity of cell wall degrading enzymes with the 
use of Carbendazim-Mancozeb fungicidal mixture is an indication of the chemical's possible reducing effect on rate of soil organic matter decomposition.

Table 1: Physicochemical Properties of Soils Collected from Different Locations Used in the study

\begin{tabular}{lccc}
\hline $\begin{array}{l}\text { Physicochemical } \\
\text { Properties }\end{array}$ & $\begin{array}{c}\text { Soil A } \\
\text { (Bolorunduro) }\end{array}$ & $\begin{array}{c}\text { Soil B } \\
\text { (Eyenkorin/Bala) }\end{array}$ & $\begin{array}{c}\text { Soil C } \\
\text { (Irrigationsite,T\&R farm) }\end{array}$ \\
\hline Clay (\%) & 8.48 & 6.48 & 8.48 \\
Silt (\%) & 3.00 & 5.00 & 8.00 \\
Sand (\%) & 88.32 & 88.52 & 83.52 \\
Textural class & Loamy sand & Sandy & Loamy sand \\
Organic matter (\%) & 0.83 & 1.06 & 1.42 \\
Carbon (\%) & 0.43 & 0.61 & 0.82 \\
C/N ratio & 0.19 & 0.21 & 0.18 \\
Nitrogen (\%) & 2.24 & 2.94 & 4.48 \\
pH & 6.40 & 6.30 & 5.90 \\
\hline
\end{tabular}

Table 2: Effects of Fungicide Concentration on Soil Microbial Population (Cfu g $\left.{ }^{-1}\right)$

\begin{tabular}{|c|c|c|c|}
\hline $\begin{array}{l}\text { Incubation Time } \\
\text { Fungi } * \text { (cfu (Days) } \\
\mathrm{g}^{-1} \text { soil }\end{array}$ & $\begin{array}{c}\text { Concentration } \\
\mathbf{m g ~ k g}^{-1} \\
\left.\mathbf{x 1 0 ^ { 3 }}\right)\end{array}$ & $\begin{array}{l}\text { Actinomycetes } \\
\left(\begin{array}{c}\text { colony } \mathbf{g}^{-1} \text { soil } \\
\left.\mathbf{x 1 0 ^ { 7 }}\right)\end{array}\right.\end{array}$ & 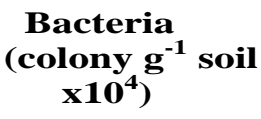 \\
\hline $\mathrm{O}$ & 66.78 & 28.00 & 2.44 \\
\hline 7 & 1.67 & 29.00 & 23.11 \\
\hline 0.39 & 2.34 & 25.56 & 13.84 \\
\hline 0.18 & $\mathrm{O}$ & 68.28 & 129.89 \\
\hline \multicolumn{4}{|l|}{2.83} \\
\hline 14 & 1.67 & 29.17 & 20.83 \\
\hline 1.11 & 2.34 & 9.22 & 11.39 \\
\hline 0.83 & $\mathrm{O}$ & 70.17 & 131.56 \\
\hline \multicolumn{4}{|l|}{3.17} \\
\hline 21 & 1.67 & 28.72 & 31.89 \\
\hline 1.89 & 2.34 & 18.56 & 25.28 \\
\hline 1.28 & 0 & 70.17 & 131.56 \\
\hline \multicolumn{4}{|l|}{3.17} \\
\hline 28 & 1.67 & 28.72 & 31.89 \\
\hline 1.89 & 2.34 & 18.56 & 25.28 \\
\hline 1.28 & $\mathrm{O}$ & 73.06 & 144.56 \\
\hline \multicolumn{4}{|l|}{4.50} \\
\hline 60 & 1.67 & 42.11 & 100.61 \\
\hline \multicolumn{4}{|l|}{3.06} \\
\hline 2.34 & 37.11 & 76.94 & 2.17 \\
\hline LSD (0.05) & 0.676 & 0.978 & 0.101 \\
\hline
\end{tabular}

$*(\mathrm{cfu})=$ colony forming unit 
TABLE 3:Effects of Fungicide Concentration on the Population of Nitrogen Fixers and Nitrifying Bacteria (Cfu ${ }^{-1}$ )

\begin{tabular}{|c|c|c|c|c|c|}
\hline $\begin{array}{l}\text { Incubation } \\
\text { Time (Days) }\end{array}$ & $\begin{array}{c}\text { Concentration } \\
\left(\mathrm{mg} \mathrm{kg}^{-1}\right)\end{array}$ & $\begin{array}{l}\text { Aerobic } \\
\text { Nitrogen } \\
\text { Fixers } \\
\left(\text { colony g } \text { g }^{-1}\right. \\
\left.\text { soil } x \mathbf{1 0}^{4}\right)\end{array}$ & $\begin{array}{l}\text { Aerobic } \\
\text { Nitrogen } \\
\text { Fixers } \\
(\text { colony g-1 } \\
\left.\text { soil x 10 }{ }^{7}\right)\end{array}$ & $\begin{array}{c}\text { Nitrite } \\
\text { Producers } \\
\left(\text { colony } \mathbf{g}^{-1}\right. \\
\left.\text { soil } x \mathbf{1 0}^{7}\right)\end{array}$ & $\begin{array}{l}\text { Nitrate } \\
\text { Producers } \\
\left(\text { colony } \mathbf{g}^{-1}\right. \\
\left.\text { soil } \mathbf{1 0})^{7}\right)\end{array}$ \\
\hline 0 & 35.11 & 22.56 & 39.83 & 40.83 & \\
\hline \multirow[t]{3}{*}{7} & 1.67 & 14.33 & 10.50 & 12.06 & 18.50 \\
\hline & 2.34 & 9.61 & 6.78 & 7.72 & 12.44 \\
\hline & 0 & 36.44 & 25.06 & 40.89 & 42.22 \\
\hline \multirow[t]{3}{*}{14} & 1.67 & 13.67 & 10.61 & 12.44 & 18.94 \\
\hline & 2.34 & 8.83 & 7.00 & 7.78 & 14.06 \\
\hline & 0 & 38.61 & 26.56 & 42.56 & 42.83 \\
\hline \multirow[t]{3}{*}{21} & 1.67 & 16.72 & 15.50 & 19.67 & 22.22 \\
\hline & 2.34 & 12.89 & 10.78 & 15.67 & 18.83 \\
\hline & 0 & 40.00 & 28.17 & 43.22 & 44.11 \\
\hline \multirow[t]{3}{*}{28} & 1.67 & 21.11 & 22.00 & 26.28 & 28.11 \\
\hline & 2.34 & 19.94 & 18.72 & 21.39 & 24.89 \\
\hline & 0 & 44.11 & 29.50 & 50.33 & 47.72 \\
\hline \multirow[t]{3}{*}{60} & 1.67 & 30.00 & 26.11 & 34.22 & 38.39 \\
\hline & 2.34 & 26.00 & 24.89 & 29.33 & 34.39 \\
\hline & $\operatorname{LSD}(0.05)$ & 1.327 & 1.121 & 1.172 & 1.178 \\
\hline
\end{tabular}


TABLE 4: Effects of Fungicide Concentration on Celluloytic Bacterial and Fungal Population in Soil $\left(\mathrm{Cfu} \mathrm{g}^{-1}\right)$

\begin{tabular}{|c|c|c|c|}
\hline $\begin{array}{l}\text { Incubation Time } \\
\text { (Days) }\end{array}$ & $\begin{array}{l}\text { Concentration } \\
\left(\mathrm{mg} \mathrm{kg}^{-1}\right)\end{array}$ & $\begin{array}{c}\text { Cellulolytic } \\
\text { Bacteria }\left(\text { colony } \mathbf{g}^{-1}\right. \\
\left.\text { Soil x10 }{ }^{7}\right)\end{array}$ & $\begin{array}{c}\text { Cellulolytic } \\
\text { Fungi }\left(\mathrm{cfu} \mathrm{g}^{-1}\right. \\
\left.\text { soil } \times 1^{4}\right)\end{array}$ \\
\hline & 0 & 15.89 & 4.83 \\
\hline \multirow[t]{3}{*}{7} & 1.67 & 6.83 & 1.06 \\
\hline & 2.34 & 5.61 & 0.56 \\
\hline & 0 & 16.44 & 4.94 \\
\hline \multirow[t]{3}{*}{14} & 1.67 & 7.28 & 1.89 \\
\hline & 2.34 & 6.39 & 0.94 \\
\hline & 0 & 16.78 & 4.67 \\
\hline \multirow[t]{3}{*}{21} & 1.67 & 10.11 & 2.21 \\
\hline & 2.34 & 8.94 & 1.76 \\
\hline & 0 & 18.78 & 5.33 \\
\hline \multirow[t]{3}{*}{28} & 1.67 & 17.00 & 3.56 \\
\hline & 2.34 & 15.28 & 2.75 \\
\hline & 0 & 22.00 & 5.61 \\
\hline \multirow[t]{3}{*}{60} & 1.67 & 23.89 & 4.06 \\
\hline & 2.34 & 21.22 & 3.44 \\
\hline & $(0.05)$ & 1.071 & 1.446 \\
\hline
\end{tabular}

$*(\mathrm{cfu})=$ colony forming unit

TABLE 5: Effects of Fungicide Concentration on Cellulase and Pectinase Activities in Soil

\begin{tabular}{|c|c|c|c|}
\hline Incubation Time (Days) & $\begin{array}{c}\text { Concentration } \\
\left(\mathrm{mg} \mathrm{kg}^{-1} \text { soil }\right)\end{array}$ & $\begin{array}{c}\text { Cellulase } \\
\text { Activity } \\
\text { (Units) }\end{array}$ & $\begin{array}{l}\text { Pectinase } \\
\text { Activity } \\
\text { *(V.R.U) }\end{array}$ \\
\hline \multirow{4}{*}{7} & 0 & 0.144 & 5.317 \\
\hline & 1.67 & 0.052 & 3.898 \\
\hline & 2.34 & 0.024 & 2.896 \\
\hline & 0 & 0.172 & 5.428 \\
\hline \multirow[t]{3}{*}{28} & 1.67 & 0.070 & 4.246 \\
\hline & 2.34 & 0.035 & 3.138 \\
\hline & 0 & 0.190 & 5.777 \\
\hline \multirow[t]{3}{*}{60} & 1.67 & 0.095 & 4.928 \\
\hline & 2.34 & 0.100 & 3.908 \\
\hline & $(\mathbf{0 . 0 5})$ & 0.0286 & 1.183 \\
\hline
\end{tabular}

* $($ VRU $)=$ Viscosity Reducing Unit 


\section{CONCLUSION}

The Carbendazim-Mancozeb fungicidal mixture, "TEAM" though a useful tool in the control of fungal diseases should be used with caution. The study has shown that the use of rate higher than recommended one does not offer any advantage in the control of the target group. The recommended rate of application of the fungicide should therefore be adhered to in view of its effects on non-targeted ecologically important groups of microorganisms particularly at concentrations higher than recommended rate.

\section{ACKNOWLEDGEMENTS}

We thank Mr. Mohammed A.A, Mr. Luqman and Mr. Majasan of the Department of Agronomy University of Ilorin, Ilorin Nigeria, for their technical assistance. Useful comments and contributions of Prof. A.J Afolayan of Phytomedicine Research Group, Department of Botany, University of Fort Hare, Alice, South Africa are acknowledged. 
Jitka, C, Jiri ,J., Jakub, H.( 2009). Fungicides mancozeb and dinocap on carbon and nitrogen mineralization in soils. Ecotoxicology and Enviromental Safety 72: (1) 80-85

JMPR monographs (1995). Carbendazim. In Pesticides residues in foodEvaluations part II Toxicological and Environmental, Joint meeting on pesticide report.

Lawrence, C.H. (1956). A method of isolating actinomycetes from scabby potato tissue and soil with minimal contamination: Can. J. Bot. 34: 44-47.

Miller, G. L. (1959). Use of dinitrosalicylic acid reagent for determination of reducing sugar. Analytical chemistry 31, 426-428.

Mitchell, R.R, Summer, C.L, Blonde, S.A, Bush, D.M, Hurlburt, G.K, Snyder, E.M., and Giesy, J.P. (2002) SCRAM: A scoring and ranking system for persistent, bioaccumulative, and toxic substances for the North American Great Lakes resulting chemical scores and rankings. Human Ecol Risk Assess 8: (3) 537-557.

Pozo, C., Rodelas,V.,Salmeron, M. V., Martinez-Toledo, G and Vela, R.(1994) Effects of Fungicides Maneb and Mancozeb on soil microbial populations Toxicological and Environmental chemistry 43 (3\&4):123-132.

Robot ,K.A, Barath, P.L. (1972). Viscometric method for assessing pectolytic and cellulytic enzyme produced by Rhizopus stolonifer: Phythopathology 49:145148.

Staples, D.G. (1973). An introduction to microbiology.In: Macmillan Education Ltd, London and Basingstoke. : 78-79

US EPA 2000. Pesticide ecotoxicity database, office of pesticide programs. Environmental Fate and Effects Division: US EPA Washington DC

Vyas S.C. 1988. Non-target effects of agricultural fungicides: CRL Press Boca Roton, Florida.

Walkey, A, Black, J.A. (1934). An Examination of the Deytyare method of determining soil organic matter and proposed modification of the chromic titration method. Soil Science 37: 29-38.

WHO/FAO (1997). Joint meeting on pesticides residues (JMPR) Carbendazim (07). 